\title{
Evolution of Calcite-Bearing Kimberlites by Melt-Rock Reaction - Evidence from Polymineralic Inclusions within Clinopyroxene and Garnet Megacrysts from Lac de Gras Kimberlites, Canada
}

\author{
Yannick Bussweiler ${ }^{1}$, Rebecca S. Stone ${ }^{1}$, D. Graham Pearson ${ }^{1}$, Robert W. Luth ${ }^{\mathbf{1}}$, \\ Thomas Stachel $^{1}$, Bruce A. Kjarsgaard ${ }^{2}$, Andrew Menzies ${ }^{3}$ \\ ${ }^{1}$ University of Alberta,Edmonton, Canada, bussweil@ualberta.ca \\ ${ }^{2}$ Geological Survey of Canada, Ottawa, Canada \\ ${ }^{3}$ Universidad Católica del Norte, Antofagasta, Chile
}

\begin{abstract}
Introduction
Polymineralic inclusions are fully crystallized melt inclusions commonly found in megacrysts from kimberlites. Since the 1970s, such inclusions have been reported to occur in a variety of phases from different locations. Haggerty and Boyd (1975) first documented inclusions in olivine megacrysts from the Monastery kimberlite, South Africa, and interpreted them as an early kimberlite melt with an immiscible sulphide liquid. Schulze (1985) described inclusions in clinopyroxene and garnet megacrysts from Kentucky, USA, and suggested that they represent the megacryst magma from which the host crystals formed. Van Achterbergh et al. (2002) interpreted inclusions in Cr-diopsides from Lac de Gras, Slave Craton, Canada, as trapped primary carbonatitic melt, that may have differentiated towards more silicic melts (van Achterbergh et al. 2004; Araújo et al. 2009). A striking commonality of these reports is that the inclusions are carbonate-rich and typically contain high modal proportions of calcite. However, from high-pressure, high-temperature experiments it is well established that carbonates at mantle depths, and by extension carbonate-rich melts in the mantle, must be Mg-rich, i.e., dolomite or magnesite (Wyllie and Huang 1975; Brey et al. 1983; Dalton and Presnall 1998). The presence of calcite within polymineralic inclusions was previously interpreted to be a result of unmixing and quenching in the final stages of kimberlite emplacement (van Achterbergh et al. 2002). Here we document carbonate-rich polymineralic inclusions in clinopyroxene and garnet megacrysts from the Diavik and Ekati diamond mines, Lac de Gras, Canada. The inclusions provide mineralogical and chemical evidence for an origin of kimberlite involving the reaction of a siliceous dolomitic magma with diopside-bearing mantle assemblages to produce a melt that crystallizes a calcite-dominated assemblage in the crust (Bussweiler et al. 2016).
\end{abstract}




\section{Results}
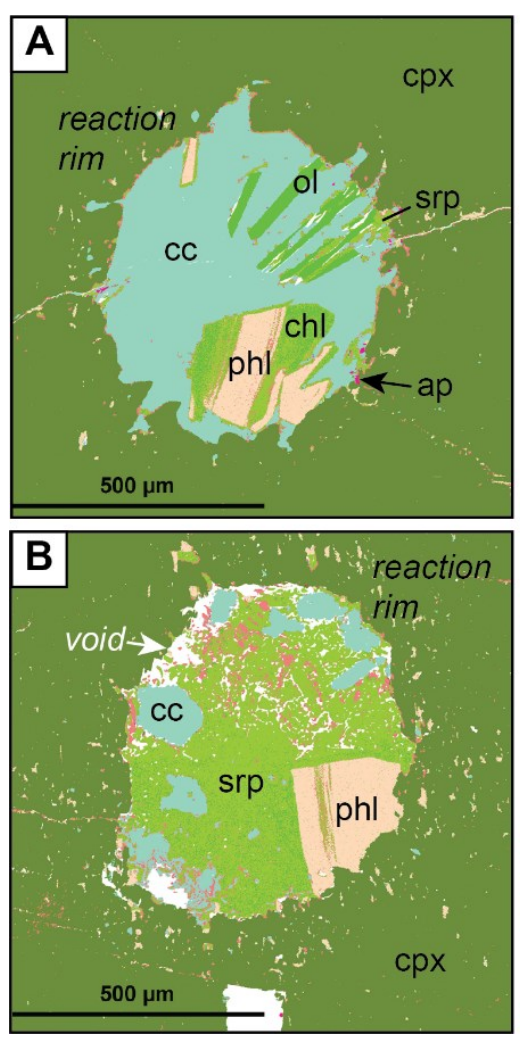

Figure 1: QEMSCAN images clinopyroxene (Cr-diopside) and garnet (Cr-pyrope) megacrysts from Lac de Gras kimberlites.
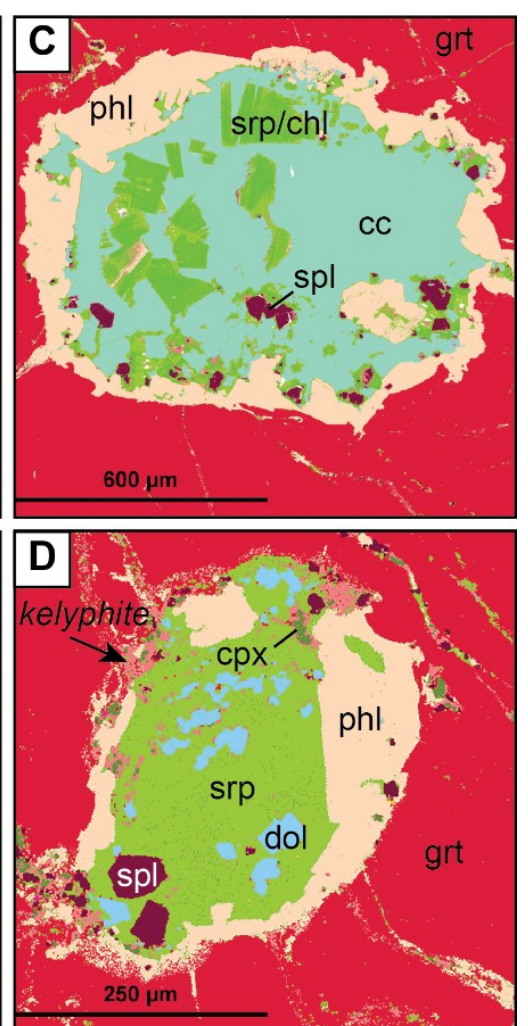

of polymineralic inclusions in
Polymineralic inclusions in $\mathrm{Cr}$ diopside megacrysts commonly contain the phases calcite, phlogopite, serpentine/chlorite, olivine, and chromite/spinel (Fig.1a,b). The inclusions are surrounded by reaction rims, similar to spongy rims, and trails of fluid inclusions $\left(\mathrm{CO}_{2}\right.$-rich) extend from the polymineralic inclusions. Phases within polymineralic inclusions in garnet (Cr-pyrope) megacrysts are the same as those in clinopyroxenes, but further include Al-rich cpx, Al-spinel, and Ni-sulfide (Fig. $1 \mathrm{c}, \mathrm{d})$. Importantly, carbonates within polymineralic inclusions in garnet can be more Mg-rich (dolomite and Mg-calcite). Polymineralic inclusions in garnet are commonly surrounded by kelyphite-like rims. The mineral chemistry of the inclusion phases

olivine, phlogopite, chomite/spinel, and serpentine (EPMA) is overall consistent with that of early magmatic kimberlite mineral phases, but indicates extensive reaction with the host minerals; compared to equivalent phases in kimberlites, the inclusion phases are enriched in $\mathrm{Cr}, \mathrm{Al}$, and $\mathrm{Mn}$. Trace element signatures of phlogopite within the inclusions (LA-ICP-MS) constrain their crystallization from the melt inclusions at lithospheric mantle depths. The textural evidence for disequilibrium between polymineralic inclusions and their host crystals is supported by Sr isotopes (SIMS). For the complete dataset the reader is referred to Bussweiler et al. (2016).

\section{Discussion}

Bulk compositions of the inclusions (Fig. 2) were reconstructed using modal proportions obtained by QEMSCAN (Fig. 1), and mineral compositions measured by EPMA. Reconstructed bulk compositions of the inclusions bear a general resemblance to experimentally derived partial melts of carbonated peridotites and to previous estimates of primary kimberlite magmas, but indicate assimilation of mantle minerals (e.g., orthopyroxene) including the host minerals clinopyroxene and garnet (Fig. 2). Thus, we propose that the polymineralic inclusions represent snapshots of kimberlite melt reacting with the lithospheric mantle during ascent. Importantly, inclusions in Cr-diopside record direct evidence for a decarbonation reaction of the form: dolomitic melt + diopside $\rightarrow$ forsterite + calcite $+\mathrm{CO}_{2}$, which is expected to begin at pressures $<2.5 \mathrm{GPa}$ (Stone and Luth 2016). This reaction may play an important role, along with other decarbonation reactions (e.g., Abersteiner et al. 2017), in the en-route transformation of an upward moving dolomitic silico-carbonatite melt into the calcite-bearing kimberlite observed at the surface. 


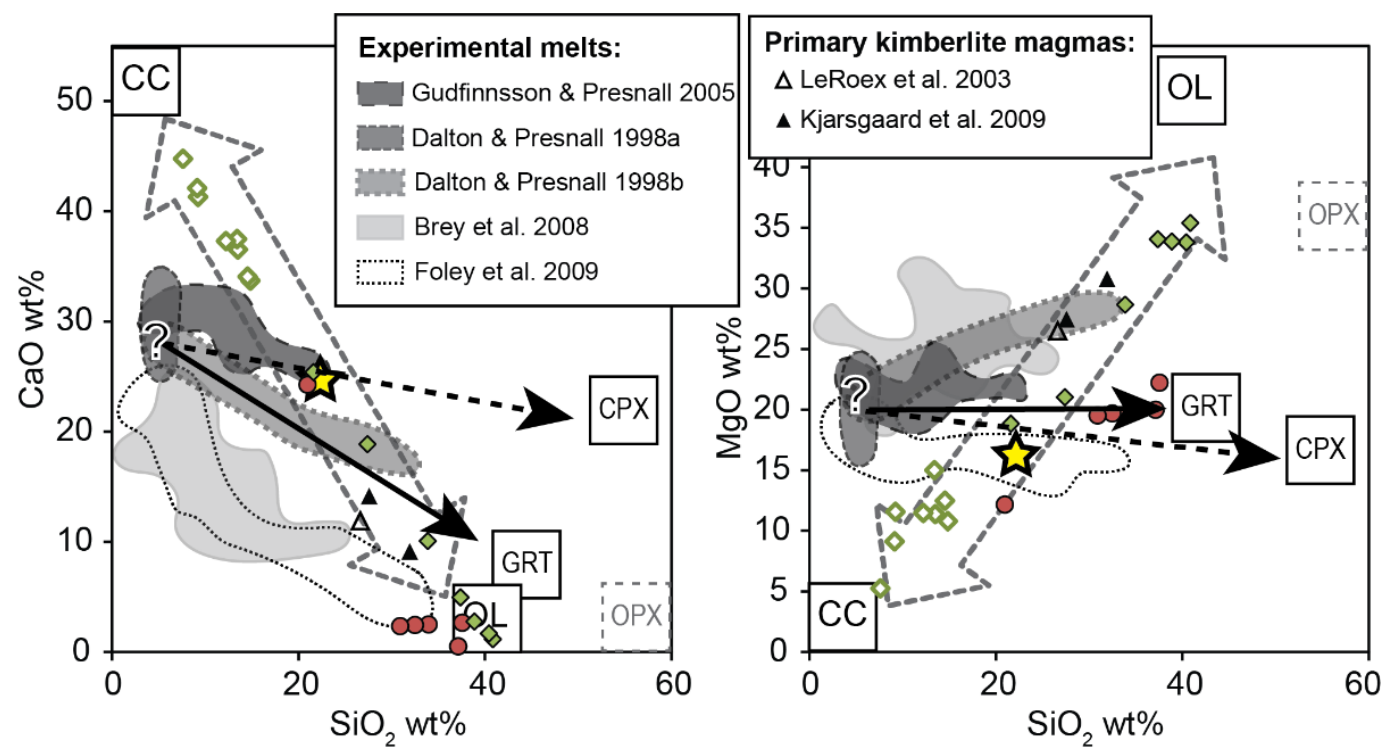

Figure 2: Reconstructed bulk compositions of polymineralic inclusions (green diamonds = in Cr diopsides; red circles $=$ in Cr-pyropes) plot along a linear array (dashed, gray, double-arrow field) due to sectioning effects. An average composition (star symbol) can be related to partial melts of carbonated peridotite produced in high-P-T experiments by reaction with the host phases (cpx, grt) and orthopyroxene (opx).

\section{References}

Abersteiner A, Kamenetsky VS, Pearson DG, et al (2017) Monticellite in Group-I kimberlites: Implications for evolution of parental melts and post-emplacement $\mathrm{CO} 2$ degassing. Lithos In Press

Araújo DP, Griffin WL, O’Reilly SY (2009) Mantle melts, metasomatism and diamond formation: Insights from melt inclusions in xenoliths from Diavik, Slave Craton. Lithos 112:675-682.

Brey G, Brice WR, Ellis DJ, et al (1983) Pyroxene-carbonate reactions in the upper mantle. Earth Planet Sci Lett 62:63-74.

Bussweiler Y, Stone RS, Pearson DG, et al (2016) The evolution of calcite-bearing kimberlites by melt-rock reaction: evidence from polymineralic inclusions within clinopyroxene and garnet megacrysts from Lac de Gras kimberlites, Canada. Contrib to Mineral Petrol 171:65.

Dalton J, Presnall D (1998) Carbonatitic melts along the solidus of model lherzolite in the system $\mathrm{CaO}-\mathrm{MgO}-\mathrm{A} 12 \mathrm{O} 3-\mathrm{SiO} 2-\mathrm{CO} 2$ from 3 to $7 \mathrm{GPa}$. Contrib to Mineral Petrol 131:123-135.

Haggerty SE, Boyd FR (1975) Kimberlite inclusions in an olivine megacryst from Monastery. In: De Beers Kimberlite Symposium I. Cambridge,

Schulze D (1985) Evidence for primary kimberlitic liquids in megacrysts from kimberlites in Kentucky, USA. J Geol 93:75-79.

Stone RS, Luth RW (2016) Orthopyroxene survival in deep carbonatite melts: implications for kimberlites. Contrib to Mineral Petrol 171:63.

van Achterbergh E, Griffin WL, Ryan CG, et al (2002) Subduction signature for quenched carbonatites from the deep lithosphere. Geology 30:743.

van Achterbergh E, Griffin WL, Ryan CG, et al (2004) Melt inclusions from the deep Slave lithosphere: implications for the origin and evolution of mantle-derived carbonatite and kimberlite. Lithos 76:461-474.

Wyllie PJ, Huang WL (1975) Peridotite, kimberlite, and carbonatite explained in the system CaO$\mathrm{MgO}-\mathrm{SiO} 2-\mathrm{CO} 2$. Geology 621-624. 